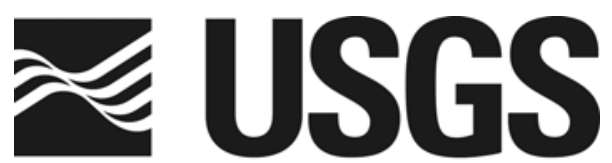

science for a changing world

\title{
Capitol Lake, Washington, 2004 Data Summary
}

By Jodi Eshleman, Peter Ruggiero, Etienne Kingsley, Guy Gelfenbaum, and Doug George

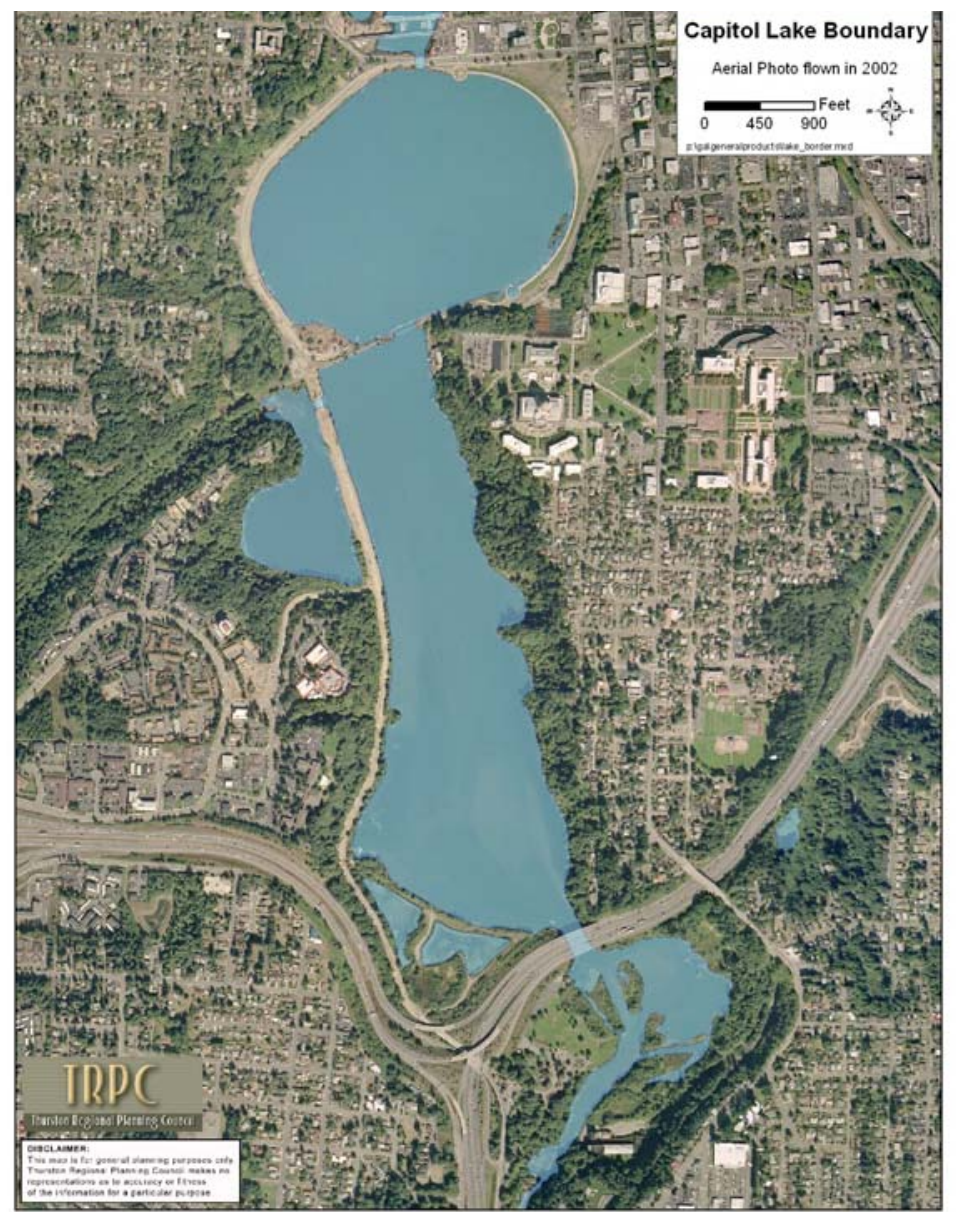

Photo courtesy of Thurston, Wash., Regional Planning Council.

Data Series 180

U.S. Department of the Interior

U.S. Geological Survey 



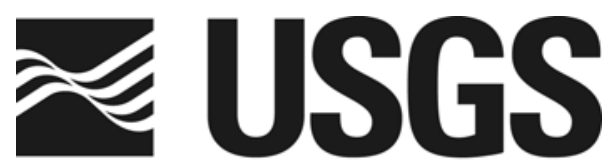

science for a changing world

\section{Capitol Lake Washington 2004 Data Summary}

Jodi Eshleman, Peter Ruggiero, Etienne Kingsley, Guy Gelfenbaum, and Doug George

Data Series 180

U.S. Department of the Interior

U.S. Geological Survey 



\section{Table of Contents}

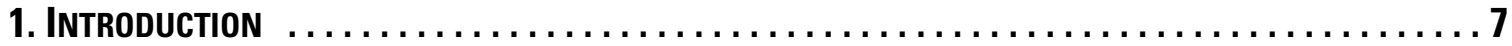

2. Data Collected $\ldots \ldots \ldots \ldots \ldots \ldots \ldots \ldots \ldots \ldots \ldots \ldots \ldots \ldots \ldots \ldots \ldots \ldots \ldots \ldots$

2.1 Bathymetry Data $\ldots \ldots \ldots \ldots \ldots \ldots \ldots \ldots \ldots \ldots \ldots \ldots \ldots \ldots \ldots \ldots \ldots \ldots \ldots \ldots, \ldots$

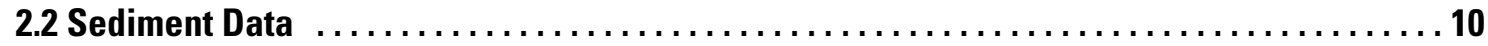

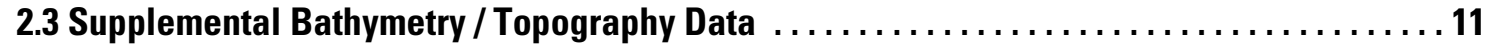

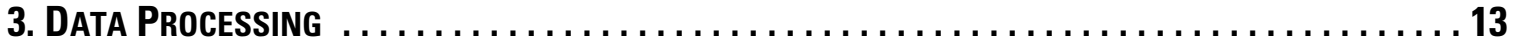

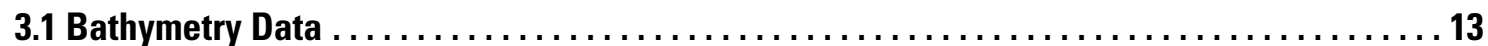

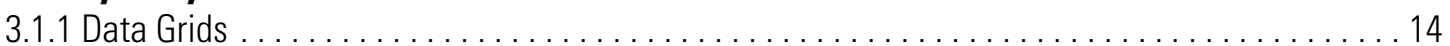

3.1 .2 Individual Lines . . . . . . . . . . . . . . . . . . . . . . . . . . . . . . . 16

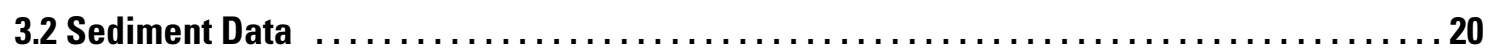

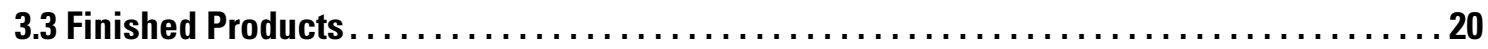

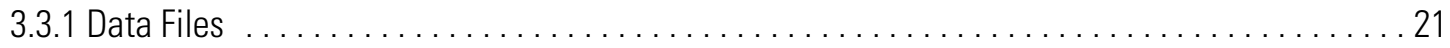

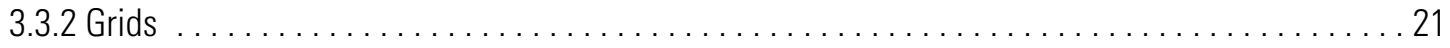

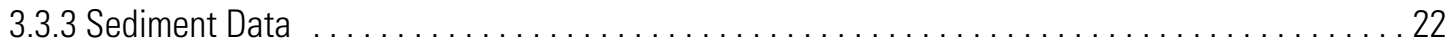

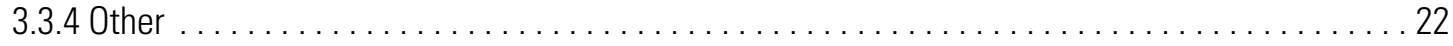

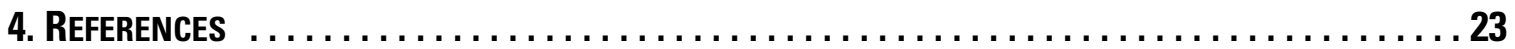

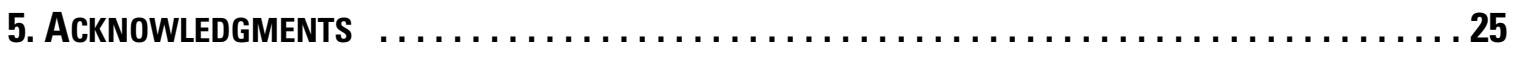

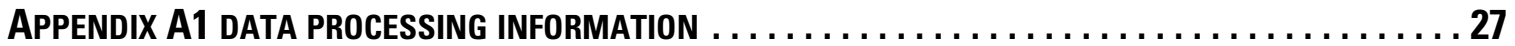

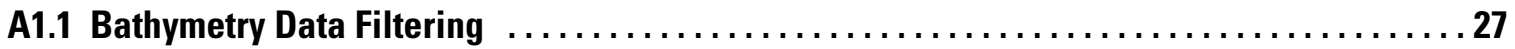

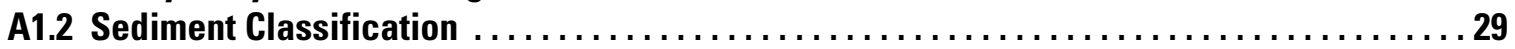





\section{Figures}

1.

2.

3.

4.

5.

6.

7.

8.

9.

10.

11.

12.
Location of Capitol Lake, Wash., at the southern end of Budd Inlet in Puget Sound $\ldots \ldots \ldots \ldots \ldots .7$

Second generation Coastal Profiling System being prepared for data collection $\ldots \ldots \ldots \ldots \ldots \ldots . . . . .6$

(A) Planned data coverage and (B) Actual data collected ......................... 10

Sediment sampling locations in Capitol Lake ...................................11

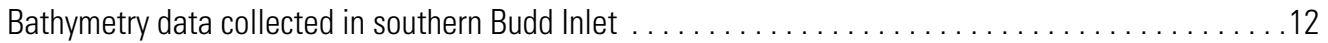

Bathymetry / topography data collected by Washington Department of Ecology and Washington Department of Fish and Wild life in Capitol Lake ....................................... 13

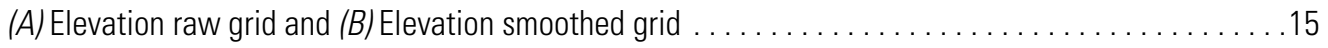

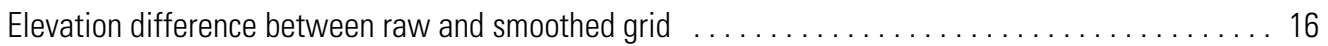

Line location and numbering system for the north and middle basin. . . . . . . . . . . . . . . 17

Raw and smoothed data for line 6 using a minimum filter and averaging over $5 \mathrm{~m} \ldots \ldots \ldots \ldots . \ldots 18$

Raw and smoothed data for line $37 \mathrm{using}$ a median filter and averaging over $5 \mathrm{~m} \ldots \ldots \ldots \ldots . \ldots 19$

Raw and smoothed data for line 56 using a combination of minimum and median filters averaging over $5 \mathrm{~m}$ along

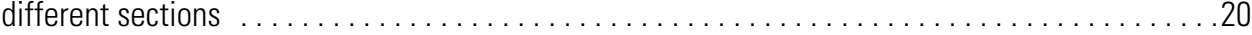





\section{Tables}

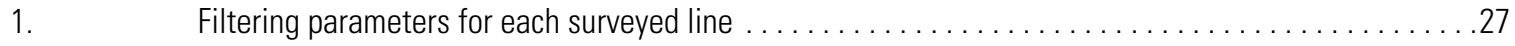

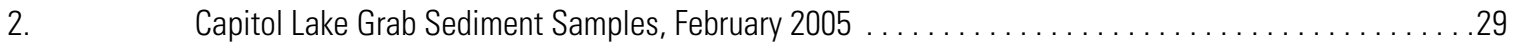





\section{INTRODUCTION}

At the request of the Washington Department of Ecology (WDOE), the US Geological Survey (USGS) collected bathymetry data in Capital Lake, Olympia, Wash., on September 21, 2004 (fig. 1). The data are to be used to calculate sediment infilling rates within the lake as well as for developing the bottom boundary conditions for numerical models of water quality, sediment transport, and morphological change. In addition, the USGS collected sediment samples in Capitol Lake in February, 2005, to help characterize bottom sediment for numerical model calculations and substrate assessment.

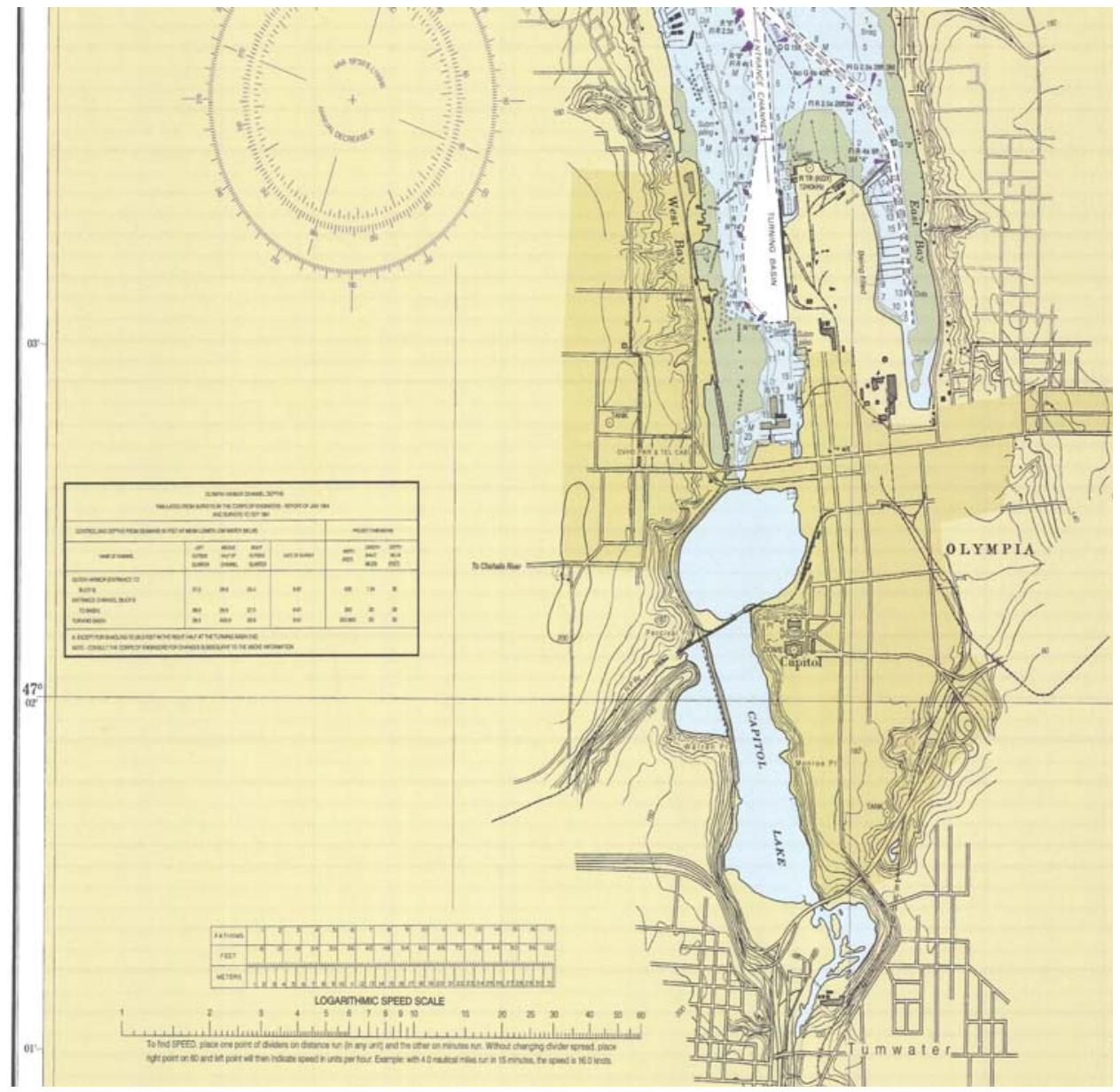

Figure 1. Location of Capitol Lake, Wash., at the southern end of Budd Inlet in Puget Sound (National Oceanic and Atmospheric Association 2004). 


\section{Data Collected}

\subsection{Bathymetry Data}

The Coastal Profiling System (CPS), a hydrographic surveying system mounted on a personal watercraft (PWC), was used to collect bathymetric data in Capital Lake (fig. 2).

Combining the high accuracy positioning of a Differential Global Positioning System (DGPS), the efficiency of an acoustic echo sounder, and the mobility of a personal watercraft, the CPS provides a fast and accurate method to obtain sub-aqueous bathymetric profiles. Repeatability tests suggest this technique achieves subdecimeter accuracy (MacMahan, 2001); however, reasonable variations in water temperature and salinity (not measured) can affect depth estimates by as much as 3 percent of the water depth. This data was collected assuming a sound velocity of $1500 \mathrm{~m} / \mathrm{s}$. For freshwater, this value is probably closer to $1,450 \mathrm{~m} / \mathrm{s}$ and would affect depth estimates for most of this data by only approximately $5 \mathrm{~cm}$, due to the shallow depth in most of the lake. A more complete discussion of specifics regarding the CPS can be found in Ruggiero and others (in press) and MacMahan (2001). 


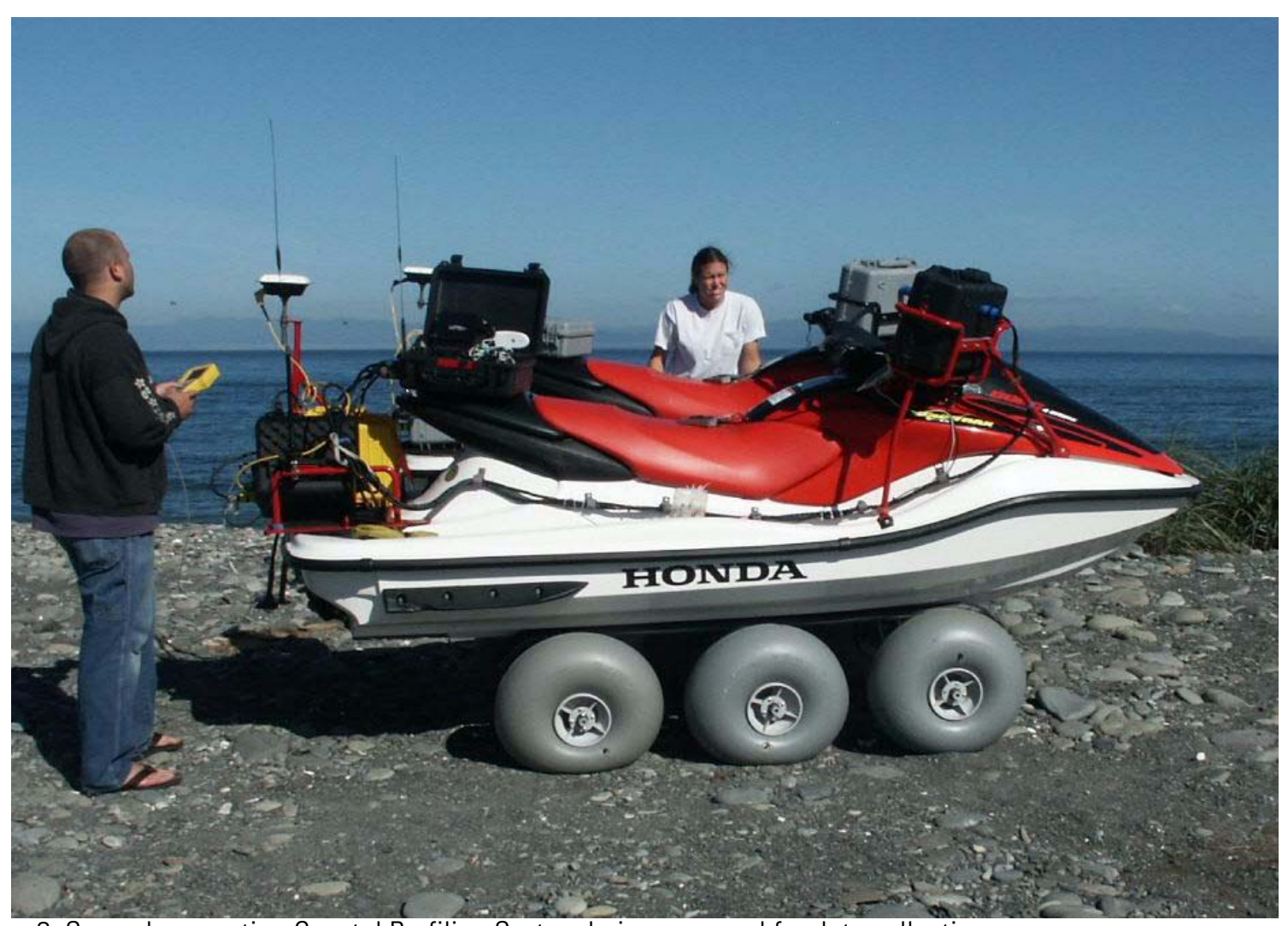

Figure 2. Second generation Coastal Profiling System being prepared for data collection.

The planned survey lines (developed in collaboration with Mindy Roberts at WDOE) and the actual data collected are shown in fig. 3. Line spacing is approximately $10 \mathrm{~m}$ in the north basin and $20 \mathrm{~m}$ in the south basin. The data were collected using Real Time Kinematic (RTK) Global Positioning System (GPS). The benchmark used for the survey was DP4 with the Washington State Plane South NAD 83 coordinates of northing 192002.104 m, easting $316708.187 \mathrm{~m}$, and an elevation of $4.561 \mathrm{~m}$ (NAVD 88). The data were collected in this same coordinate system. Lines 1-4 were too shallow for any reasonable data to be collected with this system. The gaps in the southern part of the middle basin are due to dense weed infestations. We could not access Percival Basin and the South Basin proved too shallow and choked with vegetation to apply our survey approach. 

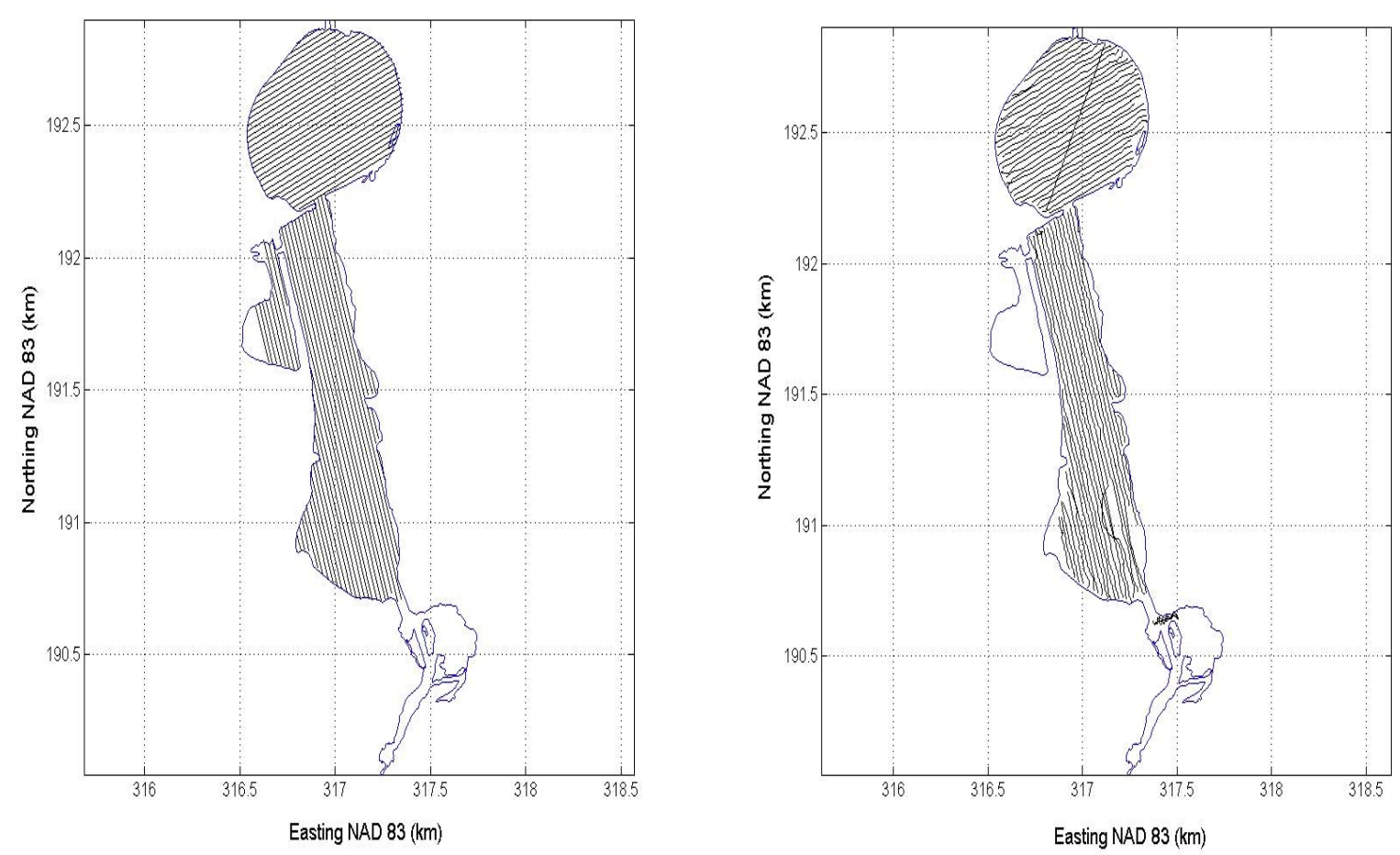

Figure 3. (A) Planned data coverage and (B) Actual data collected.

\subsection{Sediment Data}

Seventy-three surficial sediment samples were collected with a clamshell grab by outboard motorboat in February 2005 (fig. 4). Thirty samples were gathered from North Basin, 31 from Middle Basin and 13 from South Basin. Positions were identified by a hand-held Garmin GPS and depth was recorded from an onboard echo sounder. Approximately $300 \mathrm{~g}$ of sediment per sample were placed in plastic bags and stored in a cooler for transport. Two of these samples are not included in the results because of a missing GPS location or missing sample. 


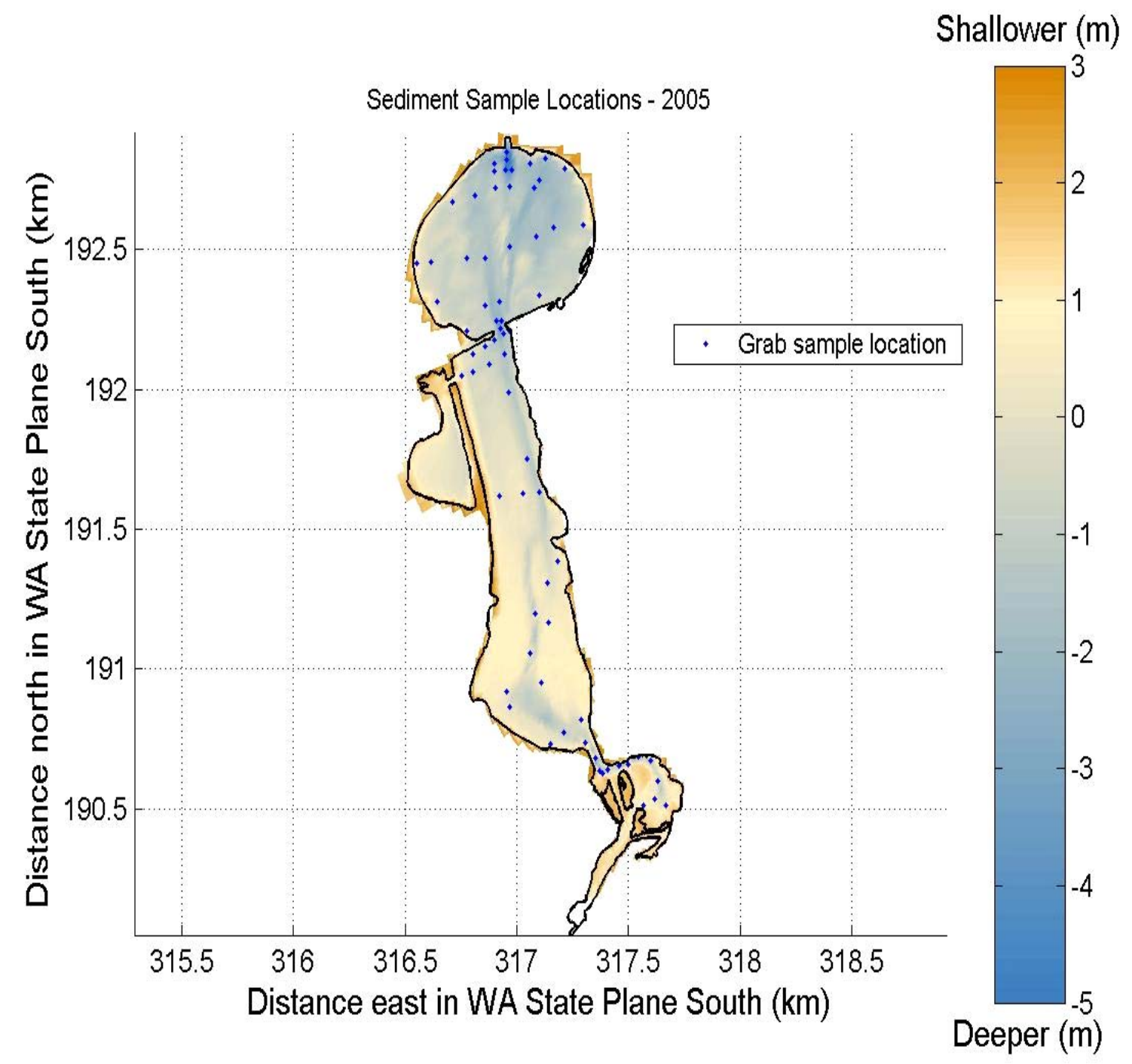

Figure 4. Sediment sampling locations in Capitol Lake.

\subsection{Supplemental Bathymetry / Topography Data}

To augment this dataset and help provide recent bathymetry for modeling studies, some additional bathymetric data was collected using the CPS in southern Budd Inlet on March 18, 2005 (fig. 5). The benchmark used for the survey was DP6 with the Washington State Plane 
South NAD 83 coordinates of northing 192870.128 m, easting $316837.539 \mathrm{~m}$, and an elevation of $5.098 \mathrm{~m}$ (NAVD 88).

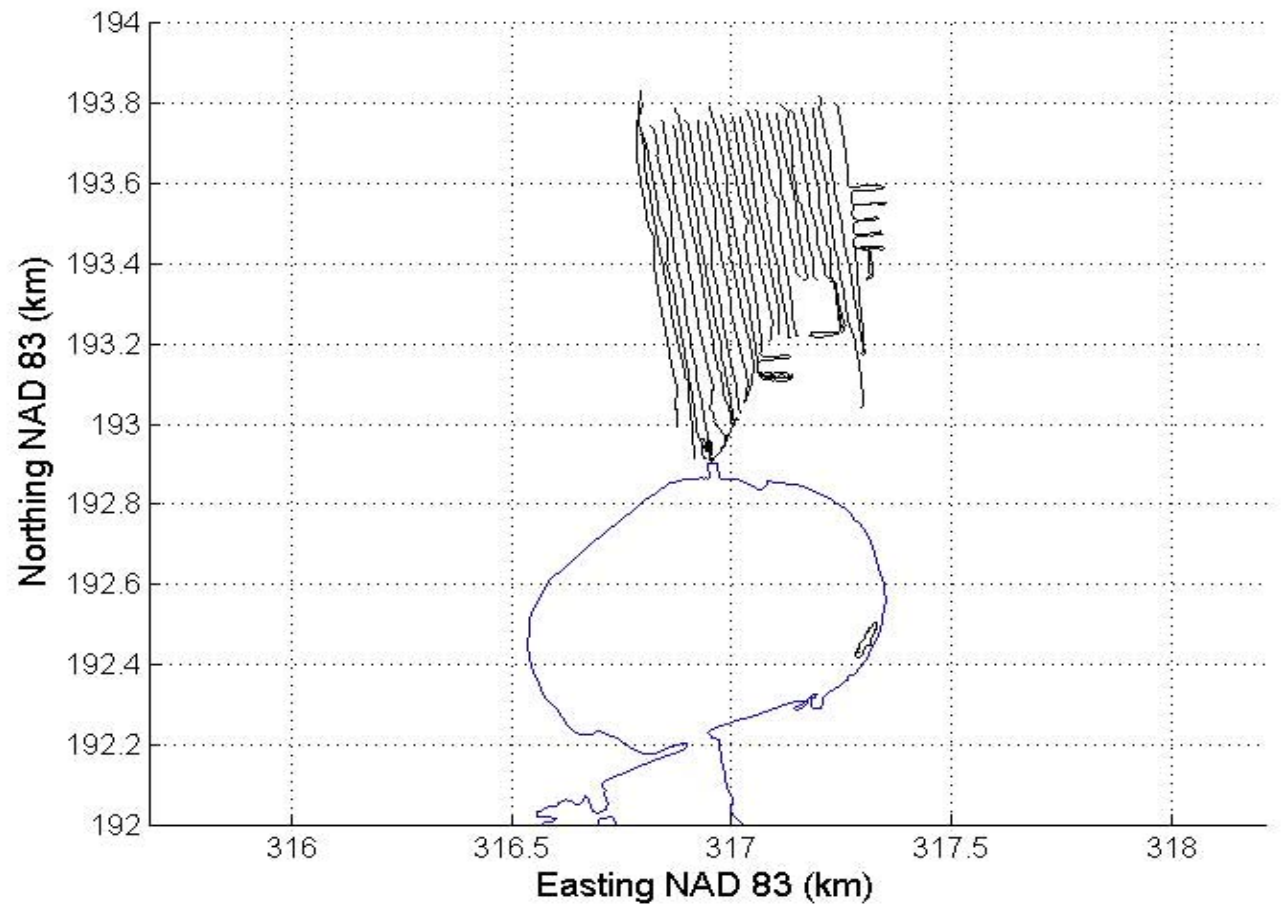

Figure 5. Bathymetry data collected in southern Budd Inlet.

Percival and South Basin proved too shallow for the CPS. To remedy this problem, the Washington Department of Ecology (WDOE) collected bathymetry/topography data in both areas using the RTK GPS system mounted on a pole (fig. 6). This data was collected using the DP4 benchmark described in Section 2.1. The CPS was also unable to collect data under the Interstate 5 bridge because the GPS system is limited by satellite availability. The Washington Department of Fish and Wildlife collected data in this location in March, 2005, using an aluminum boat and 
Topcon total station (fig. 6). They estimate the accuracy of the data to be $+/-0.1 \mathrm{ft}$ in elevation and $+/-1.0 \mathrm{ft}$ in horizontal.

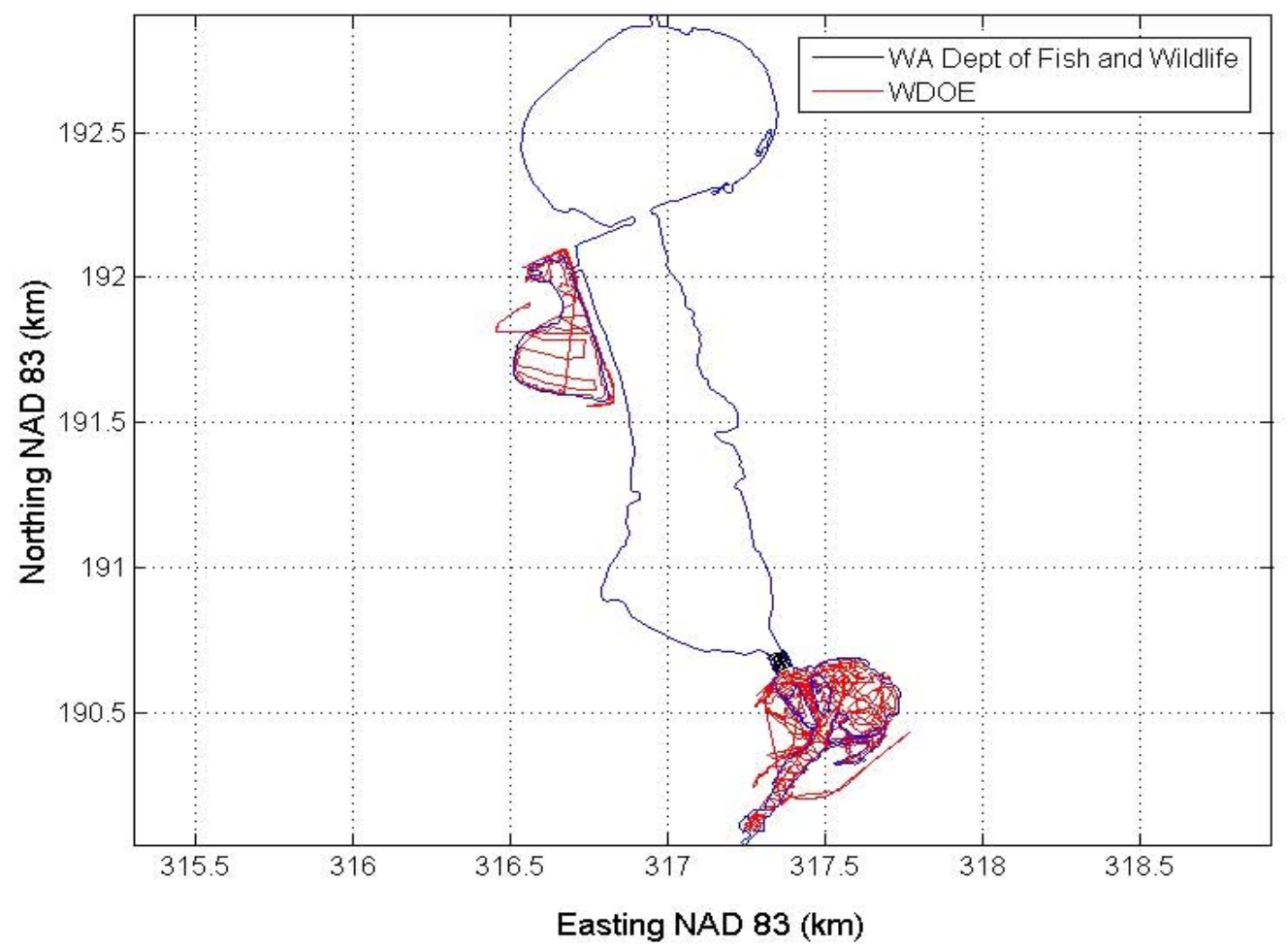

Figure 6. Bathymetry/topography data collected by Washington Department Of Ecology and Washington Department of Fish and Wildlife in Capitol Lake.

\section{Data Processing}

\subsection{Bathymetry Data}

We applied several processing steps to the bathymetric data. 
1 Outlier/Bad GPS Elimination: Each individual transect is examined to detect and remove any obvious outliers from the raw files that are either shallower than the echo sounder blanking interval or deeper than a user defined cutoff value.

2 Export: Individual files are then exported in easting, northing, elevation ASCII triplets with one data file per transect.

3 Smoothing: A smoothing operation is performed using a median (or minimum) filter on the $\mathrm{z}$ coordinate in the alongline direction to reduce high frequency fluctuations. Varying window sizes are used to obtain a smooth profile while maintaining the integrity of the actual data points.

A major concern with the Capital Lake data is the presence of aquatic weeds within the water column. In areas with extensive plant growth, the echosounders give a return representative of somewhere within the plant canopy, not necessarily from the actual bottom. We have applied several smoothing techniques to the data and determined that the most successful method was to filter individual lines in sections, using a minimum filter for areas with aquatic weeds and a median filter in sections where plant growth was absent. Although the minimum filter does a decent job of capturing the bottom of noisy sections of data, it sometimes gives an estimate of the bottom that is too low. We estimate that the mean difference between the actual bottom and the bottom estimate from the minimum filter is approximately $10 \mathrm{~cm}$ through visual observation. To counteract this problem, we add a $10 \mathrm{~cm}$ vertical offset to the minimum filtered sections where this is the case. Table 1 in appendix A presents the filtering details for each line, including the type of filter used for specific portions of the line, the filtering distance, and whether or not a vertical offset was added to any section. 


\subsubsection{Data Grids}

Gridded surfaces of the raw and filtered data are shown in fig. 7 for comparison. The grids were created using linear interpolation with a grid cell spacing of $d x=d y=5 m$. Interpolated data that were more than $25 \mathrm{~m}$ away from a data point in the $\mathrm{x}$-direction (easting) and $10 \mathrm{~m}$ away in the $y$-direction (northing) were not included to preserve the integrity of the dataset. The major difference in the grids generated from raw and filtered data is evident in areas with a high density of plant growth.

a

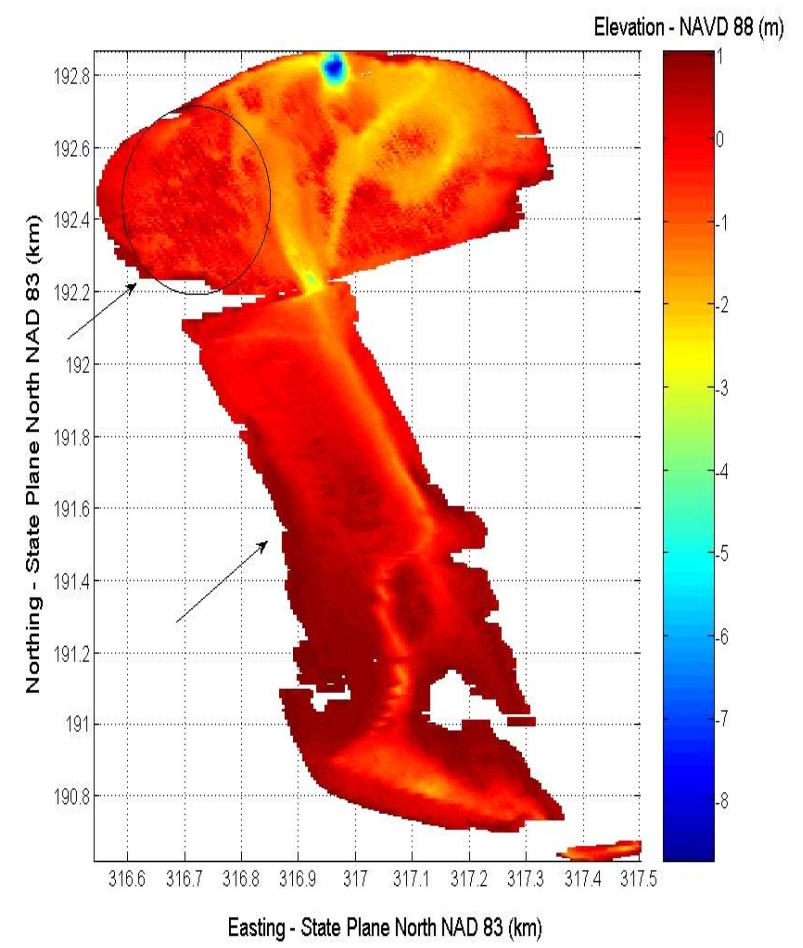

b.

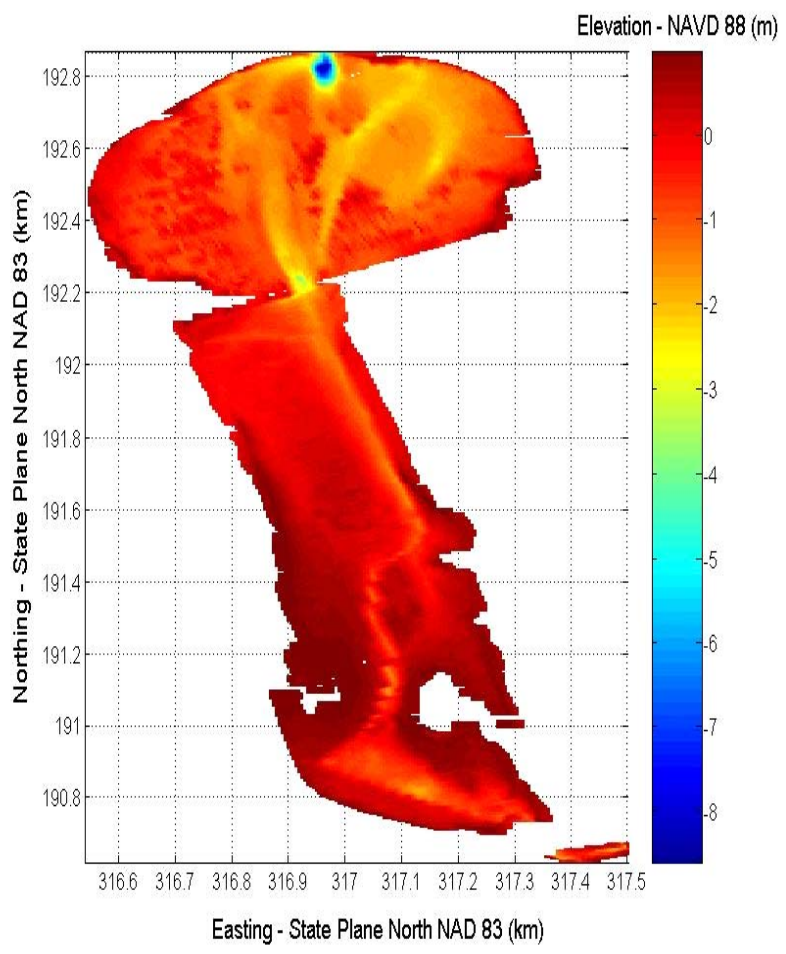

Figure 7. (A) Elevation raw grid (arrows designate sections of dense plant growth) and (B) Elevation smoothed grid. (These plots are in Washington State Plane South NAD 83 m and NAVD 88 m.)

The difference between the raw and filtered gridded data, representing what was removed in the smoothing process, is shown in fig. 8. This reveals the areas of significant plant growth and is consistent with visual observations while in the field. 


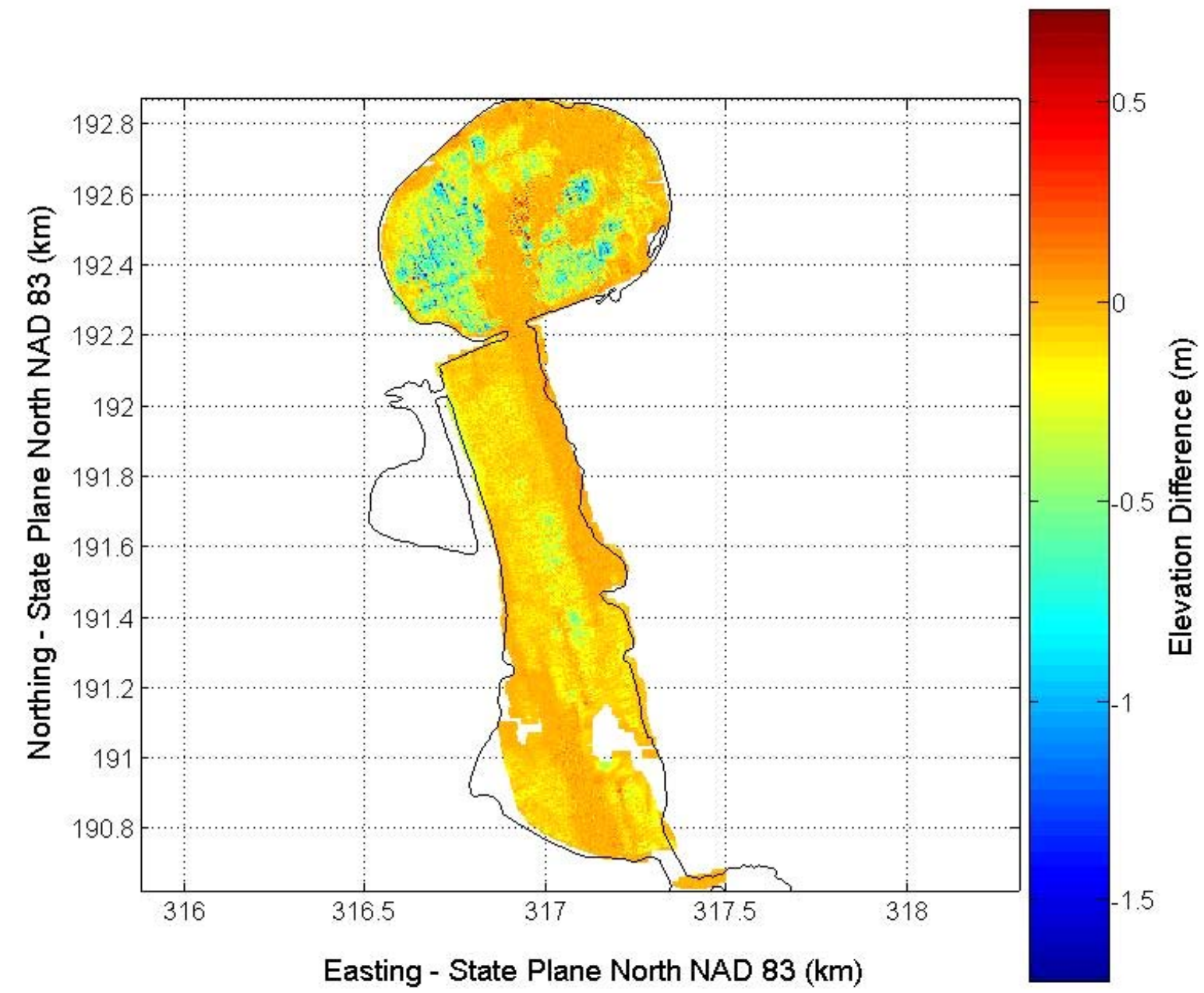

Figure 8. Elevation difference between raw and smoothed grid. Areas of light green and blue are areas of high plant density.

\subsubsection{Individual Lines}

The location of each individual bathymetric transect is included in fig. 9. Plots of raw versus smoothed data for three individual lines provide an overview of the different smoothing types applied (fig. 10,11,12). All smoothing was completed in the coordinate system used to 
collect the data (Washington State Plane South NAD $83 \mathrm{~m}$ and NAVD $88 \mathrm{~m}$ ); therefore the smoothing distance and offset values are in metric units.

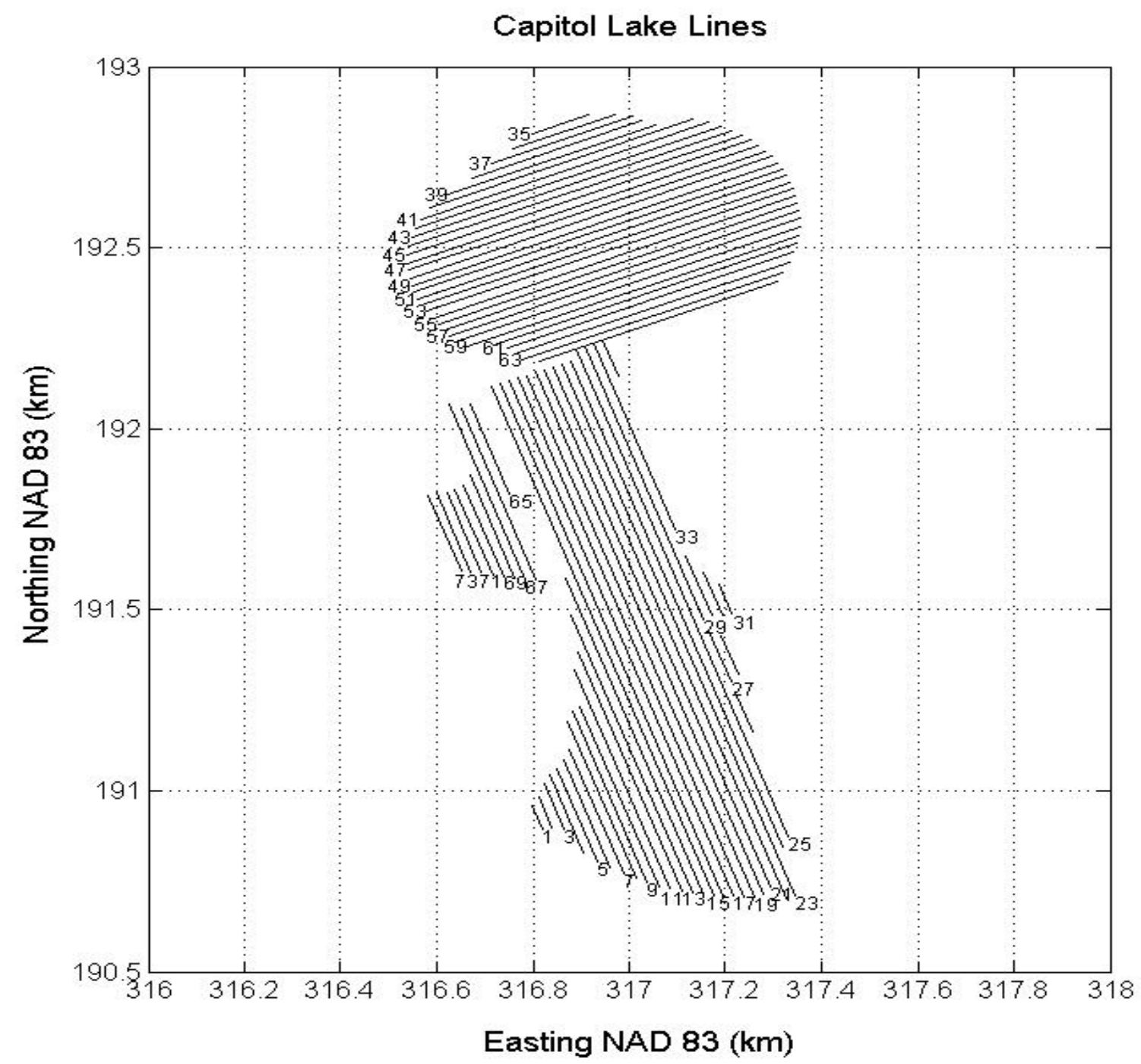

Figure 9. Line location and numbering system for the north and middle basin.

Line 6 is on the far western side of the middle basin, fig. 10. A minimum filter over $5 \mathrm{~m}$ was applied to capture the elevation of the lake bottom, presumably at the base of the aquatic weeds. This filter determines the number of points for a distance of $5 \mathrm{~m}$ and takes the minimum 
value over that number of points. The original endpoints are used for the smoothed endpoints since the filter forces the data to zero at a boundary.

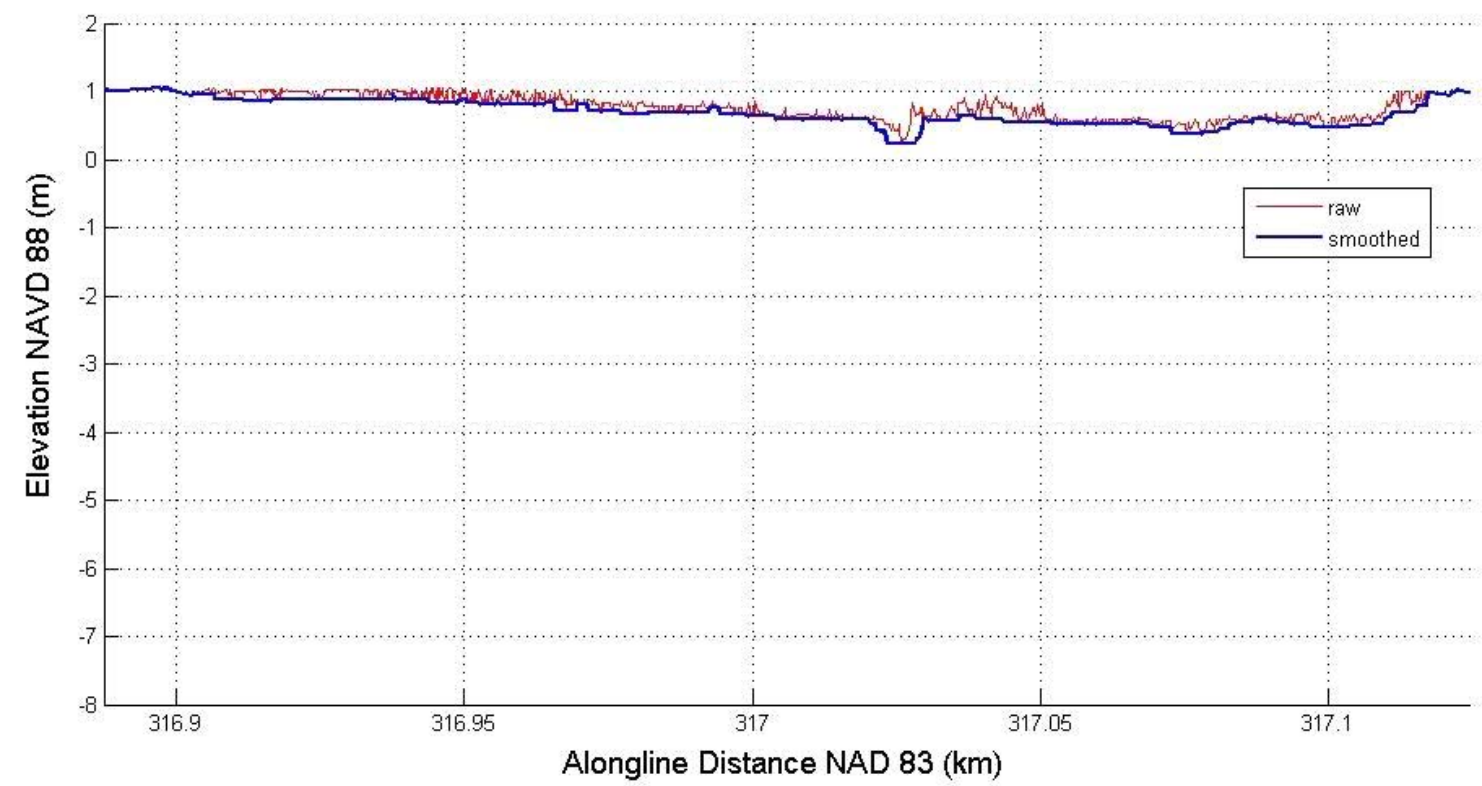

Figure 10. Raw and smoothed data for line 6 using a minimum filter and averaging over $5 \mathrm{~m}$.

Line 37 is in the northern portion of the north basin, fig. 11. A median filter over $5 \mathrm{~m}$ was applied. The median filter performed well for this case, since there were no aquatic weeds. 


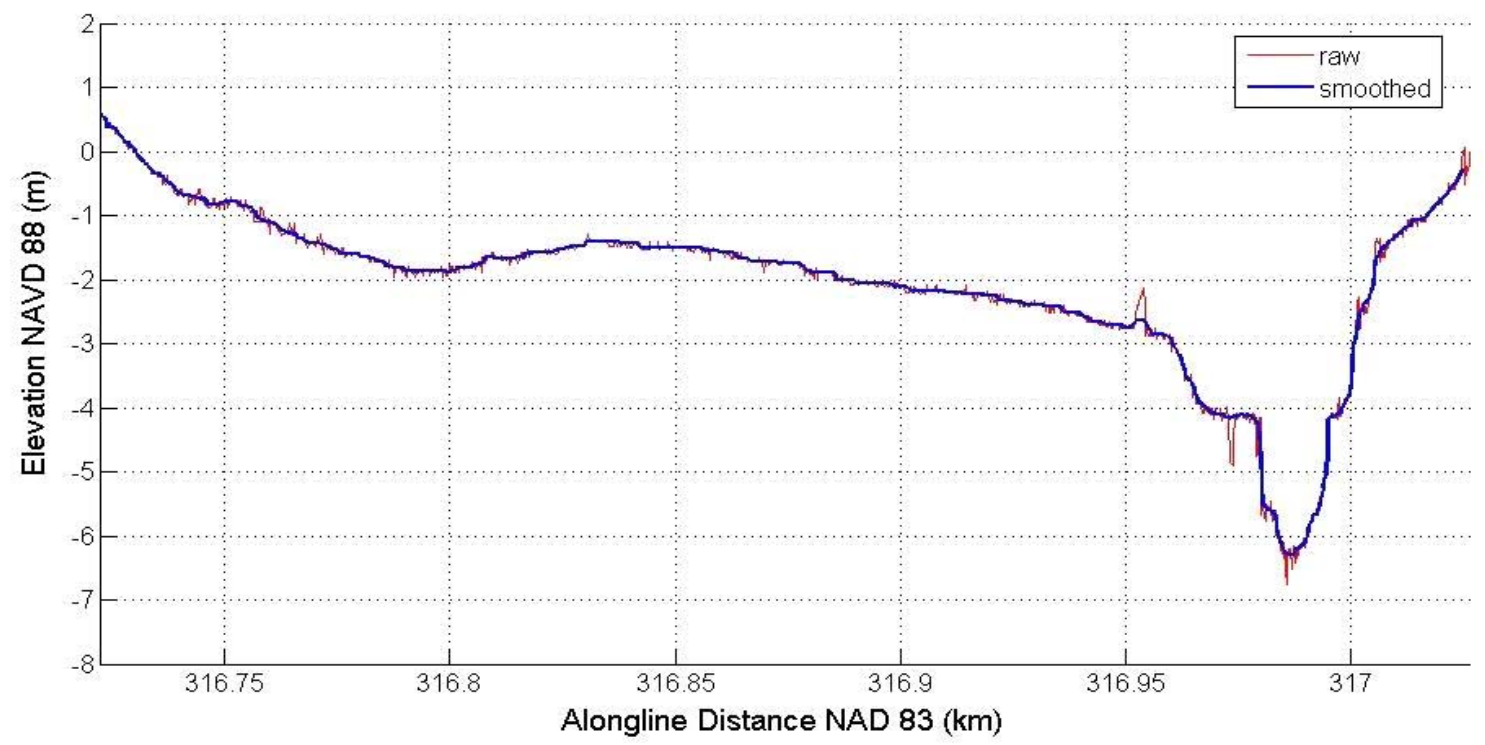

Figure 11. Raw and smoothed data for line 37 using a median filter and averaging over $5 \mathrm{~m}$.

Line 56 is in the southern portion of the north basin, fig. 12. A minimum filter over $5 \mathrm{~m}$ was applied to the outer sections and a median filter over $5 \mathrm{~m}$ was applied to the middle section. No offsets were added. It is important to note that the along line variability in this profile that results from the minimum filter does not necessarily represent actual bedform dimensions. While our smoothing approach is meant to develop the best gridded surface for the overall data set, the presence of aquatic weeds still causes sufficient noise such that we are unable to resolve small scale bedforms in several sections of the lake. 


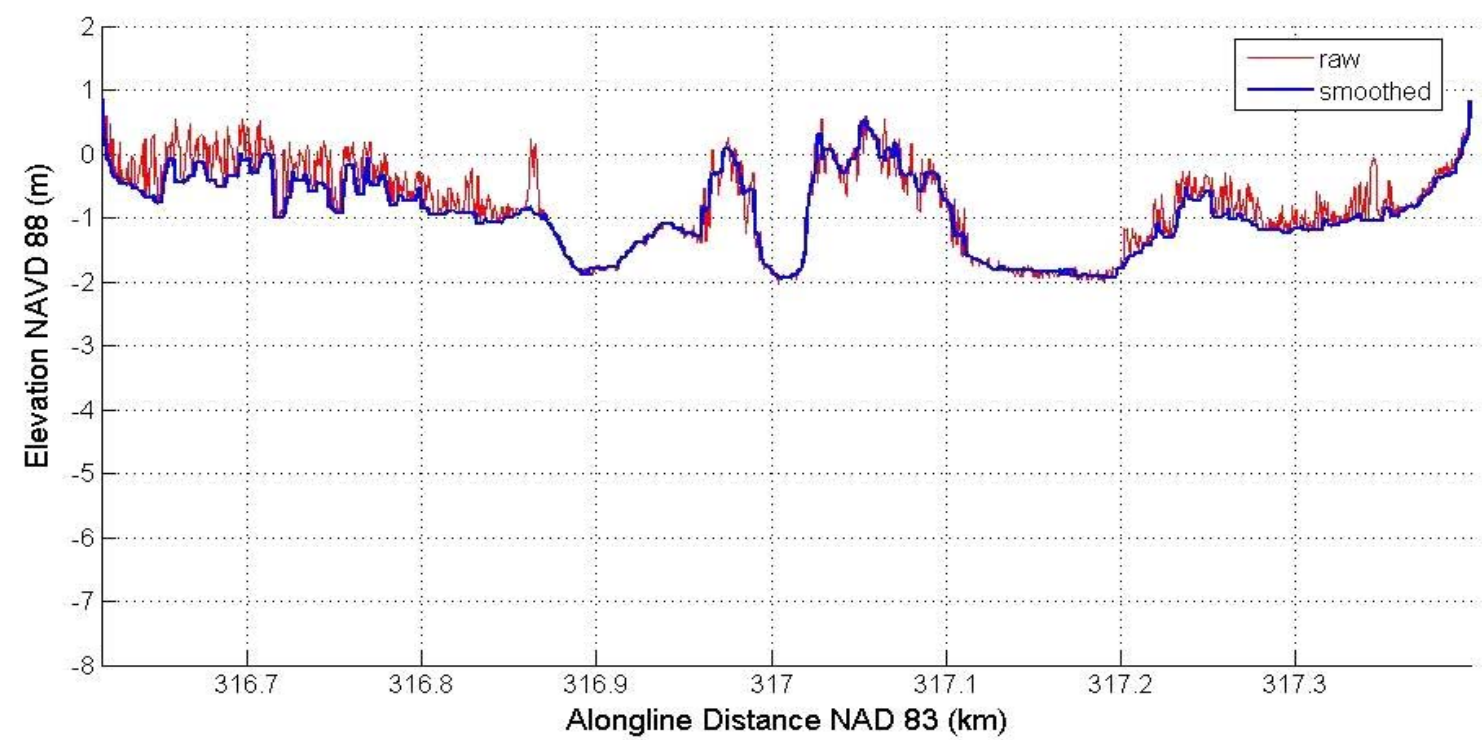

Figure 12. Raw and smoothed data for line 56 using a combination of minimum and median filters averaging over $5 \mathrm{~m}$ along different sections.

\subsection{Sediment Data}

The samples were analyzed in the Sediment Laboratory at the US Geological Survey Menlo Park campus. Each sediment sample was homogenized by handshaking the bag to ensure all grain sizes would be represented in a sub-sample. Approximately $50 \mathrm{~g}$ of sediment was placed in crucibles, dried overnight at $80^{\circ} \mathrm{C}$ and homogenized by mortar and pestle. Sediment descriptions of clay, silt, sand, and gravel were assigned to each sample based on visual inspection (appendix A). The presence of wood, leaves and shells was also noted.

\subsection{Finished Products}

Any questions, concerns, or need for additional data should be addressed to Dr. Peter Ruggiero at 650-329-5433 (pruggiero@ usgs.gov). 


\subsubsection{Data Files}

The following data are supplied on the enclosed CD. There is one data file for each line in the format c104_line001_raw.xyz for raw data and cl04_line001_sm.xyz for smoothed data. The northing and easting are in Washington State Plane - North NAD 83 (m). Elevation data are represented in meters in the NAVD 88, as this was the datum of the benchmark control point used in the survey. Column 1 is easting, column 2 is northing, and column 3 is elevation. Lines 1-34 are in the Middle Basin and correspond to lines M1-M34 supplied by WA Department of Ecology (DOE). Lines 35-64 are in the North Basin and correspond to DOE lines N1-N30. Line 65 is a diagonal line through the North Basin and is not in the planned line file. Lines 66 and 67 are lines that were driven in the South Basin to capture as much of the channel as possible.

The bathymetry data collected in southern Budd Inlet are included in a separate data file bi05_data_raw.xyz. This dataset has not been smoothed as described above, since aquatic weeds were not present in this area.

The files c105_wdoe_sb_raw.xyz and cl05_wdoe_pc_raw.xyz contain the data collected by WDOE in South Basin and Percival Cove, respectively. These files are in the same format and coordinate system as described above. The data collected under the Interstate 5 Bridge by Washington Department of Fish and Wildlife are included in c105_I5_raw.xyz. These additional data files have not been processed and are included in their raw form.

\subsubsection{Grids}

Also provided are grids of both the raw data and the smoothed data collected in Capitol Lake by the CPS, see fig. 7. Both were gridded with a grid cell size of $5 \mathrm{~m}$. Interpolated data that were more than $25 \mathrm{~m}$ away from a data point in the $\mathrm{x}$-direction and $10 \mathrm{~m}$ away in the $\mathrm{y}$-direction 
were eliminated. The files names are cl04grid_raw.xyz for raw data and c104grid_sm.xyz for smoothed data. These grid files have a similar format of xyz triplets where column 1 is Easting, column 2 is northing, and column 3 is elevation.

\subsubsection{Sediment Data}

Table 2 in Appendix A includes location information for each sample as well as the sediment description.

\subsubsection{Other}

Table 1 in Appendix A discusses the smoothing parameters used for each individual line. 


\section{REFERENCES}

MacMahan, J., 2001, Hydrographic surveying from a personal watercraft: Journal of Surveying Engineering, no.127, v.1, p.12-24.

National Oceanic and Atmospheric Administration, 2004, Olympia Harbor and Budd Inlet: U.S. Department of Commerce, National Oceanic and Atmospheric Association National Ocean Service Coast Survey Chart No.18456.

Ruggiero, P., Kaminsky, G.M., Gelfenbaum, G., and Voigt, B., in press. Seasonal to interannual morphodynamic variability along a high-energy dissipative littoral cell: Journal of Coastal Research. 


\section{ACKNOWLEDGMENTS}

We would like to thank Bob Barnard from the Department of Fish and Wildlife for providing us with bathymetry data collected under the I-5 bridge. Also, we would like to thank Laura Bauleke and Blythe Mackey from Washington Department of Ecology for collecting additional bathymetry data in Percival Cove and South Basin. 


\section{APPENDIX A1. DATA PROCESSING INFORMATION}

\section{A1.1 Bathymetry Data Filtering}

The lines collected with the CPS were smoothed to remove noise and plant material. This was accomplished by applying different types of filters to different sections of lines. The filter type specifies a median or low filter. The filter distance represents the window size used to smooth the line. Section values are determined using alongline distance and starting at zero on the north or west end. These represent specific sections of a line that were filtered using a different type of filter than the rest of the line.

- North/South Lines: alongline distance $=y(1)+\operatorname{sqrt}\left((x(1)-x)^{2}+(y-y(1))^{2}\right)$

- $\quad$ East/West Lines: alongline distance $=x(1)+\operatorname{sqrt}\left((x-x(1))^{2}+(y-y(1))^{2}\right)$

Table 1. Filtering parameters for each surveyed line ( $m=$ median, $l=l o w)$.

\begin{tabular}{|c|c|c|c|c|c|c|}
\hline Line \# & Filter Type & $\begin{array}{l}\text { Filter Distance } \\
\text { (m) }\end{array}$ & $\begin{array}{l}\text { Offset } \\
\text { (m) }\end{array}$ & $\begin{array}{l}\text { Section } \\
\text { (m) }\end{array}$ & Section Type & $\begin{array}{l}\text { Section Distance } \\
\text { (m) }\end{array}$ \\
\hline 5 & 1 & 5 & & & & \\
\hline 6 & I & 5 & & & & \\
\hline 7 & I & 5 & & & & \\
\hline 8 & I & 5 & & & & \\
\hline 9 & I & 5 & & & & \\
\hline 10 & I & 5 & & & & \\
\hline 11 & I & 5 & & & & \\
\hline 12 & $\mathrm{~m}$ & 5 & & $100-250$ & I & 5 \\
\hline 13 & $\mathrm{~m}$ & 5 & & 550 - end & I & 5 \\
\hline 14 & $\mathrm{~m}$ & 5 & & $550-750$ & I & 5 \\
\hline 15 & $\mathrm{~m}$ & 5 & & 625 - end & I & 5 \\
\hline 16 & $\mathrm{~m}$ & 5 & & 425 - end & I & 5 \\
\hline 17 & $\mathrm{~m}$ & 5 & & 450 - end & I & 5 \\
\hline 18 & I & 5 & & & & \\
\hline 19 & $\mathrm{~m}$ & 5 & & $750-1,400$ & I & 5 \\
\hline
\end{tabular}


Table 1. Filtering parameters for each surveyed line (m=median, l=low) (Continued).

\begin{tabular}{|c|c|c|c|c|c|c|}
\hline Line \# & Filter Type & $\begin{array}{l}\text { Filter Distance } \\
\text { (m) }\end{array}$ & $\begin{array}{l}\text { Offset } \\
\text { (m) }\end{array}$ & $\begin{array}{l}\text { Section } \\
\text { (m) }\end{array}$ & Section Type & $\begin{array}{l}\text { Section Distance } \\
\text { (m) }\end{array}$ \\
\hline 20 & 1 & 5 & & & & \\
\hline 21 & I & 5 & & & & \\
\hline 22 & 1 & 5 & & & & \\
\hline 23 & I & 5 & & & & \\
\hline 24 & 1 & 5 & & $300-600$ & $\mathrm{~m}$ & 5 \\
\hline 25 & $\mathrm{~m}$ & 5 & & $0-450$ & I & 5 \\
\hline 26 & I & 5 & & & & \\
\hline 27 & 1 & 5 & & & & \\
\hline 28 & I & 5 & & & & \\
\hline 29 & $\mathrm{~m}$ & 5 & & & & \\
\hline 30 & $\mathrm{~m}$ & 5 & & & & \\
\hline 31 & 1 & 5 & & 20 - end & $\mathrm{m}$ & 3 \\
\hline 32 & $\mathrm{~m}$ & 3 & & & & \\
\hline 33 & $\mathrm{~m}$ & 5 & & & & \\
\hline 34 & $\mathrm{~m}$ & 3 & & & & \\
\hline 35 & $\mathrm{~m}$ & 3 & & & & \\
\hline 36 & $\mathrm{~m}$ & 2 & & & & \\
\hline 37 & $\mathrm{~m}$ & 5 & & & & \\
\hline 38 & $\mathrm{~m}$ & 5 & & $100-175$ & I & 5 \\
\hline 39 & $\mathrm{~m}$ & 5 & & $80-340$ & I & 5 \\
\hline 40 & $\mathrm{~m}$ & 5 & & $150-375$ & I & 5 \\
\hline 41 & $\mathrm{~m}$ & 5 & & $100-375$ & I & 5 \\
\hline 42 & $\mathrm{~m}$ & 5 & & $0-250$ & I & 5 \\
\hline 43 & $\mathrm{~m}$ & 5 & & $0-500$ & I & 5 \\
\hline 44 & $\mathrm{~m}$ & 5 & & $0-525$ & I & 5 \\
\hline 45 & $\mathrm{~m}$ & 5 & & $0-500$ & I & 5 \\
\hline 46 & $\mathrm{~m}$ & 5 & & $0-525$ & I & 5 \\
\hline 47 & $\mathrm{~m}$ & 5 & & $0-325$ & । & 5 \\
\hline 48 & $\mathrm{~m}$ & 5 & & $0-300$ & I & 5 \\
\hline 49 & 1 & 10 & 0.1 (525 - end) & $275-525$ & $\mathrm{~m}$ & 5 \\
\hline 50 & I & 10 & 0.1 (525 - end) & $300-525$ & $\mathrm{~m}$ & 5 \\
\hline 51 & 1 & 10 & 0.1 (500 - end) & $300-500$ & $\mathrm{~m}$ & 5 \\
\hline 52 & I & 10 & 0.1 (500 - end) & $275-500$ & $\mathrm{~m}$ & 5 \\
\hline
\end{tabular}


Table 1. Filtering parameters for each surveyed line (m=median, I=low) (Continued).

\begin{tabular}{|c|c|c|c|c|c|c|}
\hline Line \# & Filter Type & $\begin{array}{l}\text { Filter Distance } \\
\text { (m) }\end{array}$ & $\begin{array}{l}\text { Offset } \\
\text { (m) }\end{array}$ & $\begin{array}{l}\text { Section } \\
\text { (m) }\end{array}$ & Section Type & $\begin{array}{l}\text { Section Distance } \\
\text { (m) }\end{array}$ \\
\hline 53 & I & 5 & 0.1 (450 - end) & $250-450$ & $\mathrm{~m}$ & 5 \\
\hline 54 & I & 5 & 0.1 (425 - end) & $225-425$ & $\mathrm{~m}$ & 5 \\
\hline 55 & I & 10 & $0.1(0-225,350-$ end $)$ & $225-350$ & $\mathrm{~m}$ & 5 \\
\hline 56 & I & 5 & & $250-575$ & $\mathrm{~m}$ & 5 \\
\hline 57 & I & 5 & 0.1 (325 - end) & $175-325$ & $\mathrm{~m}$ & 5 \\
\hline 58 & I & 5 & & $175-375$ & $\mathrm{~m}$ & 5 \\
\hline 59 & I & 5 & 0.1 (325 - end) & $150-325$ & m & 5 \\
\hline 60 & I & 5 & & $125-275$ & $\mathrm{~m}$ & 5 \\
\hline 61 & I & 5 & & $75-250$ & $\mathrm{~m}$ & 5 \\
\hline 62 & I & 5 & 0.1 (210 - end) & $75-210$ & $\mathrm{~m}$ & 5 \\
\hline 63 & I & 5 & $0.1(0$ - 100, 225 - end $)$ & $100-225$ & m & 5 \\
\hline 64 & $\mathrm{~m}$ & 5 & & & & \\
\hline 65 & $\mathrm{~m}$ & 5 & & $275-350$ & I & 5 \\
\hline 66 & south basin & not smoothed & & & & \\
\hline 67 & south basin & not smoothed & & & & \\
\hline
\end{tabular}

\section{A1.2 Sediment Classification}

Table 2. Capitol Lake Grab Sediment Samples, February, 2005.

\begin{tabular}{|l|l|l|l|l|}
\hline Station ID & $\begin{array}{l}\text { Easting (WA State Plane } \\
\text { South NAD 83 m) }\end{array}$ & $\begin{array}{l}\text { Northing (WA State } \\
\text { Plane South NAD 83 m) }\end{array}$ & Depth (m) & Sediment Classification \\
\hline \hline CL1 & 316553.40 & 192451.90 & 5.5 & sand \\
\hline CL2 & 316614.40 & 192456.70 & 10.7 & sand, rocks \\
\hline CL3 & 316642.00 & 192313.50 & 4.1 & sand, gravel \\
\hline CL4 & 316713.60 & 192672.20 & 4.3 & sand \\
\hline CL5 & 316811.30 & 192695.30 & 7.6 & silt \\
\hline CL6 & 316752.50 & 192048.80 & 4.9 & sand \\
\hline CL7 & 316774.80 & 192208.20 & 4.0 & silt \\
\hline CL8 & 316776.00 & 192469.50 & 4.1 & silt \\
\hline CL9 & 316800.80 & 192060.60 & 3.5 & silt \\
\hline CL10 & 316804.20 & 192125.00 & 4.4 & sand, wood \\
\hline CL10B & 316856.00 & 192152.40 & 4.4 & silt \\
\hline
\end{tabular}


Table 2. Capitol Lake Grab Sediment Samples, February, 2005 (Continued).

\begin{tabular}{|c|c|c|c|c|}
\hline Station ID & $\begin{array}{l}\text { Easting (WA State Plane } \\
\text { South NAD } 83 \mathrm{~m} \text { ) }\end{array}$ & $\begin{array}{l}\text { Northing (WA State } \\
\text { Plane South NAD } 83 \mathrm{~m} \text { ) }\end{array}$ & Depth (m) & Sediment Classification \\
\hline CL11 & 316859.60 & 192469.20 & 3.7 & silt \\
\hline CL12 & 316859.80 & 192299.00 & 3.0 & sand \\
\hline CL13 & 316897.30 & 192808.40 & 3.2 & silt / sand \\
\hline CL14 & 316900.10 & 192175.50 & 2.9 & silt \\
\hline CL15 & 316951.80 & 192820.20 & 1.4 & silt \\
\hline CL16 & 316903.80 & 192721.40 & 2.5 & silt \\
\hline CL17 & 316906.70 & 192244.20 & 3.0 & silt \\
\hline CL18 & 316919.60 & 191618.80 & 3.7 & sand, shells \\
\hline CL19 & 316921.80 & 192315.00 & 4.1 & silt \\
\hline CL20 & 316928.80 & 192245.80 & 3.8 & silt \\
\hline CL21 & 316931.10 & 192245.70 & 4.3 & silt \\
\hline CL22 & 316938.00 & 192198.80 & 2.9 & silt \\
\hline CL23 & 316943.60 & 192126.00 & 3.0 & silt \\
\hline CL24 & 316877.60 & 192090.40 & 4.0 & sand, shells \\
\hline CL25 & 316950.60 & 192785.60 & 3.0 & silt \\
\hline CL26 & 316898.90 & 192778.60 & 2.7 & silt \\
\hline $\mathrm{Cl} 27$ & 316952.50 & 192847.90 & 2.4 & silt \\
\hline $\mathrm{Cl} 28$ & 316954.50 & 190919.30 & 3.7 & silt, wood, shell \\
\hline CL29 & 316955.20 & 190919.30 & 4.0 & silt / sand \\
\hline CL30 & 316965.00 & 191987.80 & 4.3 & sand, rocks \\
\hline CL31 & 316966.30 & 192726.20 & 7.6 & sand, wood \\
\hline CL32 & 316966.60 & 192512.70 & 3.0 & silt \\
\hline CL33 & 316966.50 & 192210.90 & 4.0 & sand \\
\hline CL34 & 316977.90 & 192783.70 & 4.0 & sand \\
\hline CL35 & 316924.50 & 192216.60 & 2.1 & sand, wood \\
\hline CL36 & 317027.10 & 191628.90 & 1.8 & sand \\
\hline CL37 & 317046.80 & 191751.70 & 2.1 & sand \\
\hline CL38 & 317057.40 & 191054.00 & 2.6 & sand, wood, leaves \\
\hline CL39 & 317057.80 & 192807.90 & 2.6 & silt \\
\hline CL40 & 316968.50 & 190862.60 & 3.1 & silt \\
\hline CL41 & 317079.50 & 192722.80 & 3.8 & silt \\
\hline CL42 & 317080.10 & 191197.90 & 2.6 & silt \\
\hline CL43 & 317088.60 & 192546.80 & 3.3 & silt \\
\hline
\end{tabular}


Table 2. Capitol Lake Grab Sediment Samples, February, 2005 (Continued).

\begin{tabular}{|c|c|c|c|c|}
\hline Station ID & $\begin{array}{l}\text { Easting (WA State Plane } \\
\text { South NAD } 83 \mathrm{~m} \text { ) }\end{array}$ & $\begin{array}{l}\text { Northing (WA State } \\
\text { Plane South NAD } 83 \mathrm{~m} \text { ) }\end{array}$ & Depth (m) & Sediment Classification \\
\hline CL44 & 317098.70 & 191634.50 & 1.8 & silt \\
\hline CL45 & 317100.40 & 192336.20 & 1.6 & silt, wood \\
\hline CL46 & 317100.80 & 192748.80 & 3.1 & silt \\
\hline CL47 & 317111.30 & 190951.20 & 1.4 & silt \\
\hline CL48 & 317127.50 & 192824.70 & 2.3 & silt \\
\hline CL49 & 317138.90 & 191306.20 & 3.0 & silt \\
\hline CL50 & 317139.20 & 191167.20 & 0.9 & silt \\
\hline CL51 & 317149.50 & 190732.00 & 2.9 & silt \\
\hline CL52 & 317150.30 & 190732.00 & 1.3 & silt \\
\hline CL53 & 317164.10 & 192580.00 & 1.7 & silt \\
\hline CL55 & 317184.00 & 191387.20 & 2.7 & silt \\
\hline CL56 & 317211.70 & 190774.60 & 1.4 & silt \\
\hline CL57 & 317214.70 & 192792.00 & 1.5 & silt \\
\hline CL58 & 317289.80 & 190817.90 & 2.7 & silt \\
\hline CL59 & 317296.70 & 192589.30 & 1.5 & silt \\
\hline CL60 & 317307.00 & 190735.00 & 0.8 & sand, organics \\
\hline CL61 & 317350.20 & 190680.30 & 4.3 & sand \\
\hline CL62 & 317370.20 & 190636.30 & 3.0 & gravel \\
\hline CL63 & 317382.10 & 190628.20 & 3.0 & clay \\
\hline CL64 & 317405.20 & 190637.50 & 3.7 & sand \\
\hline CL65 & 317456.70 & 190653.70 & 0.6 & gravel \\
\hline CL66 & 317498.70 & 190660.20 & 3.0 & silt / sand, leaves \\
\hline CL67 & 317543.60 & 190685.60 & 3.2 & sand, gravel \\
\hline CL68 & 317568.00 & 190512.40 & 2.7 & sand \\
\hline CL69 & 317597.90 & 190671.70 & 1.1 & silt \\
\hline CL70 & 317617.30 & 190534.30 & 1.5 & silt \\
\hline CL71 & 317629.20 & 190600.70 & 0.9 & silt \\
\hline CL72 & 317668.30 & 190510.50 & 4.3 & clay \\
\hline
\end{tabular}

